\title{
Effect of plant photosynthesis, carbon sources and ammonium availability on nitrogen fixation rates in the rhizosphere of Zostera noltii
}

\author{
David T. Welsh*, Sophie Bourguès, Rutger de Wit, Isabelle Auby** \\ Laboratoire d'Océanographie Biologique, Centre d'Océanographie et de Biologie Marine, Université Bordeaux I, \\ CNRS-URA 197, 2 rue Professeur Jolyet, F-33120 Arcachon, France
}

\begin{abstract}
Rates of nitrogen fixation (measured as acetylene reduction) in the rhizosphere of the seagrass Zostera noltii were highly dependent upon plant photosynthetic activity being significantly stimulated at elevated $\mathrm{CO}_{2}$ concentrations and by light, both in the short-term and over diurnal cycles. Stimulation by light became insignificant when $5 \mathrm{mM}$ sucrose was added to the sediment porewater. indicating that in the absence of added carbon sources, light stimulation was due to direct inputs of plant photosynthate to the rhizosphere. Addition of a range of carbon sources to the rhizosphere sediment stimulated rates of acetylene reduction, with this stimulation being significant for sucrose and lactate. Surprisingly, whilst low additions of ammonium to the sediment porewater (10 to $50 \mu \mathrm{M}$ ) inhibited $50 \%$ of acetylene reduction activity, approximately $30 \%$ of this activity persisted in the presence of $1 \mathrm{mM}$ ammonium chloride; this indicating that in at least a proportion of the $\mathrm{N}$-fixing community, nitrogenase activity was not regulated in the short term by the availability of alternative nitrogen sources.
\end{abstract}

KEY WORDS: Acetylene reduction - Nitrogen fixation - Rhizosphere - Zostera noltii . Plant photosynthesis Root exudates. Carbon sources Ammonium

\section{INTRODUCTION}

Primary productivity in coastal marine environments is generally considered to be limited by the availability of fixed nitrogen (Eppley et al. 1979). However, seagrass meadows often exhibit high levels of primary production and therefore a high demand for fixed nitrogen (Patriquin 1972, Moriarty et al. 1990). Whilst a significant proportion of this requirement can be sustained by efficient recycling of organic nitrogen within the sediment (Dennison et al. 1987, Caffrey \& Kemp 1992), heterotrophic nitrogen fixation by bacteria in the rhizosphere represents a potentially significant source of nitrogen for plant growth. Nitrogen fixation rates ranging from 0.02 to $140 \mathrm{mg} \mathrm{N} \mathrm{m}^{-2} \mathrm{~d}^{-1}$ have been measured in seagrass ecosystems and estimated to supply up to $50 \%$

\footnotetext{
·E-mail: rutger@club-internet.fr

- Present address: Station Biologique De La Tour Du Valat,

Le Sambuc, F-13200 Arles, France
}

of the fixed nitrogen requirement for plant growth $(\mathrm{Ca}$ pone 1988, O'Donohue et al. 1991, Welsh et al. 1996a).

Rates of nitrogen fixation in the rhizosphere of both sea and salt marsh grasses have been demonstrated to be influenced by the photosynthetic activity of the plants (Boyle \& Patriquin 1981, Whiting et al. 1986, O'Donohue et al. 1991, Welsh et al. 1996a) and are thought to be fuelled by the exudation of photosynthates via the plant roots. We have previously measured rates of nitrogen fixation in the seagrass meadows of the Bassin d'Arcachon, southwest France, ranging between 0.1 and $7.3 \mathrm{mg}$ $\mathrm{N} \mathrm{m}^{-2} \mathrm{~d}^{-1}$ (dependent upon growth season) and nitrogen fixation was calculated to supply between 6.3 and $12 \%$ of the annual fixed nitrogen requirement of the plant community (Welsh et al. 1996a).

In this study we have investigated the influence of plant photosynthesis and the availability of fixed nitrogen and carbon sources on nitrogen fixation activity in the rhizosphere of Zostera noltii, the dominant seagrass species in the Bassin d'Arcachon. 


\section{MATERIALS AND METHODS}

Sampling site. The sampling station was situated in an extensive seagrass meadow on the lle aux Oiseaux. a large intertidal mudflat located in the central region of the Bassin d'Arcachon (see Welsh et al. 1996a); a description of the seasonal dynamics of Zostera noltii, the dominant seagrass species, can be found in Auby \& Labourg (1996). Samples were collected between June and August 1995, with the exception of those for the diurnal cycle which were collected in October 1994, by inserting 5 or $10 \times 25 \mathrm{~cm}$ [internal diameter (i.d.)] grey plastic core tubes into the sediment until the sediment surface was level with the rims of the core tubes. The surrounding sediment was removed and the core transferred ontn a nerspex sheet for trancportation to the laboratory. At the laboratory, cores were stored at in situ temperature $\left( \pm 2^{\circ} \mathrm{C}\right)$, under semi-natural light conditions in a $50 \mathrm{~cm}$ (water depth) $\times 3 \mathrm{~m}$ tank circulated with aerated natural seawater from the Bassin (dilution rate, $\mathrm{D} \sim 0.05 \mathrm{~h}^{-1}$ ). Cores were stored maximally for $3 \mathrm{~d}$ before use.

Determination of nitrogen fixation (acetylene reduction) rates. Nitrogen fixation rates were assessed using the acetylene reduction technique. Acetylene and ethylene concentrations were determined by gas chromatography (Welsh et al. 1996a) and data corrected for the trace quantities of ethylene present in the acetylene used.

Time course experiments. Time course experiments were performed using a modification of the whole core lacunal diffusion technique (Welsh et al. 1996a). Subcores of $5 \mathrm{~cm}$ length were taken using $20 \times 4.4 \mathrm{~cm}$ (i.d.) plexiglass core tubes fitted with a Suba-sealed (W. Freeman, Barnsley, England) sampling port and 2 sets of silicon rubber sealed injection ports at $1 \mathrm{~cm}$ intervals. The water column was decanted, cores were sealed with rubber bungs, $10 \%$ of the headspace gas was replaced with acetylene via the sampling port and the cores incubated in a water bath at in situ temperature $\left( \pm 2^{\circ} \mathrm{C}\right)$ under semi-natural light conditions over a $10 \mathrm{~h}$ period. Cores for dark incubations were double wrapped in aluminium foil and incubated under the same conditions. Aliquot volumes $\left(1 \mathrm{~cm}^{3}\right)$ of the headspace gas were collected at $2 \mathrm{~h}$ time intervals and analysed for acetylene and ethylene concentrations.

Additions of sucrose and ammonium chloride to the sediment were made by 2 injections at $90^{\circ}$ at each $1 \mathrm{~cm}$ depth interval of $100 \times$ stock solutions prepared in filtersterilised seawater to give final porewater concentrations of $5 \mathrm{mM}$ for sucrose and 10,50,100 and $1000 \mu \mathrm{m}$ for ammonium; nominal porewater concentrations were based on a mean sediment porosity of $70.5 \pm 5.0 \%$ $(\mathrm{n}=5)$. Additions of $\mathrm{CO}_{2}$ to the headspace gas were made by injection via the Suba-sealed sampling port.
To determine diurnal cycles of acetylene reduction, sediment cores $(5 \times 25 \mathrm{~cm}$ i.d.) were transferred to small water baths and the water level adjusted to be level with the sediment surface. Plexigldss cure tubes $(20 \times$ $5 \mathrm{~cm}$ i.d.) were inserted into the sediment, sealed with a rubber bung, $10 \%$ of the headspace gas was replaced with acetylene and the cores incubated at ambient temperature $\left(\mathrm{ca} 25^{\circ} \mathrm{C}\right.$ ) in the dark for $6 \mathrm{~h}$ to allow equilibration of acetylene and ethylene gradients between the sediment and the headspace. Following equilibration, the cores were illuminated by tungsten light $(200 \mu \mathrm{E}$ $\mathrm{m}^{-2} \mathrm{~s}^{-1}$ ) for $12 \mathrm{~h}$ and then placed in the dark for a further $12 \mathrm{~h}$. At zero time and after subsequent $3 \mathrm{~h}$ time intervals triplicate $1 \mathrm{~cm}^{3}$ samples of the headspace gas were analysed and acetylene reduction rates calculated by subtraction of the value for the preceding $3 \mathrm{~h}$ period.

Effect of carbon sources. Sub-cores of ca $5 \mathrm{~cm}$ length were collected in $20 \times 4.4 \mathrm{~cm}$ (i.d.) plexiglass core tubes and sealed with rubber bungs. Carbon source additions were made by 2 injections at $90^{\circ}$ at each $1 \mathrm{~cm}$ depth horizon of $100 \times$ stock solutions prepared in seawater to give a final nominal porewater concentration of $5 \mathrm{mM}$. Two injections at $90^{\circ}$ to each other of $0.5 \mathrm{~cm}^{3}$ acetylene-saturated seawater were made at each $1 \mathrm{~cm}$ depth interval and $10 \%$ of the water column replaced by injection of acetylene saturated seawater; excess water was allowed to escape via a hypodermic needle inserted through the sampling port. Cores were incubated under semi-natural light conditions at in situ temperature $\left( \pm 2^{\circ} \mathrm{C}\right)$ for $3 \mathrm{~h}$.

Following incubation, a $50 \mathrm{ml}$ aliquot of the water column was transferred to a partially evacuated serum bottle containing $10 \mathrm{ml}$ of $10 \% \mathrm{v} / \mathrm{v}$ trichloroacetic acid and the bottles shaken to stop further activity. The remainder of the water column was discarded and the sediment transferred to a $360 \mathrm{ml}$ glass bottle containing $80 \mathrm{ml}$ of $10 \% \mathrm{v} / \mathrm{v}$ trichloroacetic acid. Bottles were sealed with screw tops fitted with rubber-sealed injection ports and vigorously shaken to inhibit further activity and equilibrate the dissolved gases. Following equilibration, aliquot volumes $\left(1 \mathrm{~cm}^{3}\right)$ of the headspace gas were analysed for acetylene and ethylene concentrations.

Statistical analysis. All experiments were performed in triplicate and treatment effects tested by 1-way ANOVA (Sokal \& Rohlf 1995). A posteriori comparison of the means was performed using the $T$-method.

\section{RESULTS}

\section{Influence of carbon sources}

Acetylene reduction rates (ARR) measured in control cores of Zostera noltii during both light and dark incubations were linear over the whole $10 \mathrm{~h}$ incubation 


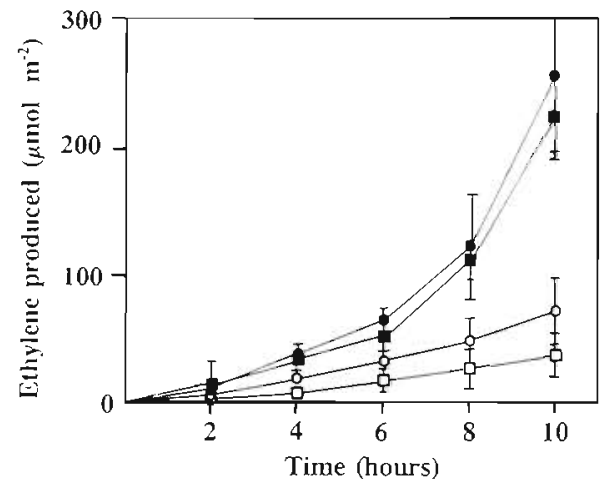

Fig. 1. Time course of ethylene production in Zostera noltiicolonised sediments during light incubations (o), dark incubations (ㅁ), light incubations of sucrose-amended cores ( $\bullet$ ) and dark incubations of sucrose-amended cores ( $\boldsymbol{\omega})$. Sucrose was added to give a final nominal porewater concentration of $5 \mathrm{mM}$ as described in the 'Materials and methods' Data points represent means for triplicate cores \pm 1 standard deviation, with the exception of the dark control data which are means of duplicate cores

period $(\mathrm{r}>0.99)$, with mean ARR of 7.66 and $4.17 \mu \mathrm{mol}$ $\mathrm{m}^{-2} \mathrm{~h}^{-1}$ for light and dark incubations, respectively (Fig. 1), being significantly different $(p<0.05$; Student's $t$-test). ARR in sucrose amended cores were linear over the first $6 \mathrm{~h}$ of incubation ( $\mathrm{r}>0.99$ ), but thereafter accelerated, with overall measured rates of 29.92 and $30.89 \mu \mathrm{mol} \mathrm{m} \mathrm{m}^{-2} \mathrm{~h}^{-1}$ for light and dark incubations, respectively, being significantly different from those of control cores $(p<0.01$; 1 -way ANOVA), but the effect of light was no longer significant ( $p=0.887$; 1 -way ANOVA). Similarly, additions of a range of carbon sources to the sediment porewater, including ethanol, sucrose, proprionate, acetate and lactate to a final nominal concentration of $5 \mathrm{mM}$ stimulated ARR by between 144 and $354 \%$ compared to those recorded for unamended control cores (data not shown). However, whilst all the tested carbon sources tended to enhance $A R R$, due to inter-core variations this stimulation was only significant for lactate and sucrose $(p<0.05$; 1 -way ANOVA), with recorded ARR of $21.56 \pm 6.57$ and $34.74 \pm 5.96 \mu \mathrm{mol} \mathrm{m} \mathrm{m}^{-2} \mathrm{~h}^{-1}$ for sucrose and lactate treated cores, respectively, as compared to $9.82 \pm$ $1.74 \mu \mathrm{mol} \mathrm{m} \mathrm{m}^{-2} \mathrm{~h}^{-1}$ for controls.

\section{Influence of plant photosynthesis}

ARR during light incubations were approximately double and significantly different $(\mathrm{p}<0.05$; Student's t-test) from those recorded during dark incubations (Fig. 1). Similarly, during artificial diurnal cycles, ARR were highly dependent on the light conditions, with ARR increasing over the first $6 \mathrm{~h}$ of incubation to a rate of $54.5 \mu \mathrm{mol} \mathrm{m} \mathrm{m}^{-2} \mathrm{~h}^{-1}$ during the 3 to $6 \mathrm{~h}$ time interval,

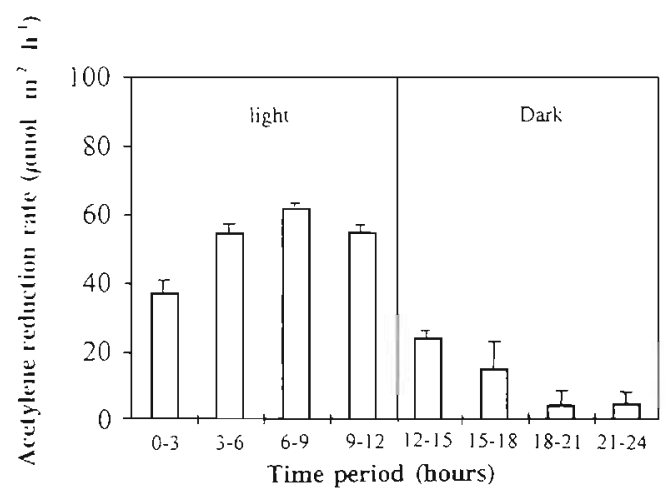

Fig. 2. Artificial diurnal cycle of acetylene reduction rates in Zostera noltii-colonised sediments. Data points represent the means of triplicate determinations and error bars signify 1 standard deviation

which was maintained throughout the remainder of the light period. On transfer to dark conditions ARR rates rapidly declined with time to below $5 \mu \mathrm{mol} \mathrm{m} \mathrm{m}^{-2}$ $\mathrm{h}^{-1}$ after $6 \mathrm{~h}$ in the dark (Fig, 2).

Additionally, increasing the $\mathrm{CO}_{2}$ concentration to $0.6 \% \mathrm{v} / \mathrm{v}$ (approx. $20 \times$ background concentrations), which would be expected to increase photosynthetic efficiency, also stimulated ARR in the rhizosphere (Fig. 3). ARR at the elevated $\mathrm{CO}_{2}$ concentration were $22.96 \pm 6.83 \mu \mathrm{mol} \mathrm{m} \mathrm{m}^{-2} \mathrm{~h}^{-1}$ compared to $10.79 \pm$ $3.69 \mu \mathrm{mol} \mathrm{m} \mathrm{m}^{-2} \mathrm{~h}^{-1}$ for controls ( $\mathrm{p}<0.01$; Student's t-test), demonstrating a clear association of ARR with plant photosynthesis.

\section{Effect of ammonium}

Additions of low concentrations of ammonium chloride to the sediment porewater rapidly inhibited ARR by 42 and $55 \%$ for nominal porewater ammonium concentrations of 10 and $50 \mu \mathrm{M}$ respectively (Fig. 4). How-

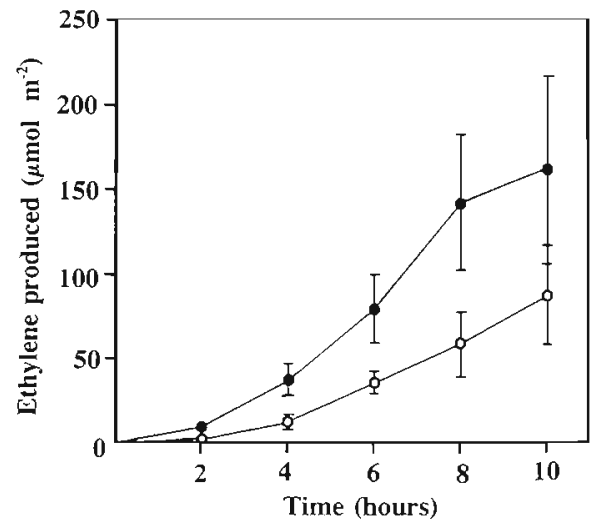

Fig. 3. Effect of headspace gas $\mathrm{CO}_{2}$ concentration on acetylene reduction activity in Zostera noltii-colonised sediments. Control (o) and $0.6 \% \mathrm{v} / \mathrm{v} \mathrm{CO}$ added $(\bullet)$. Data points represent mean values for triplicate cores \pm 1 standard deviation 


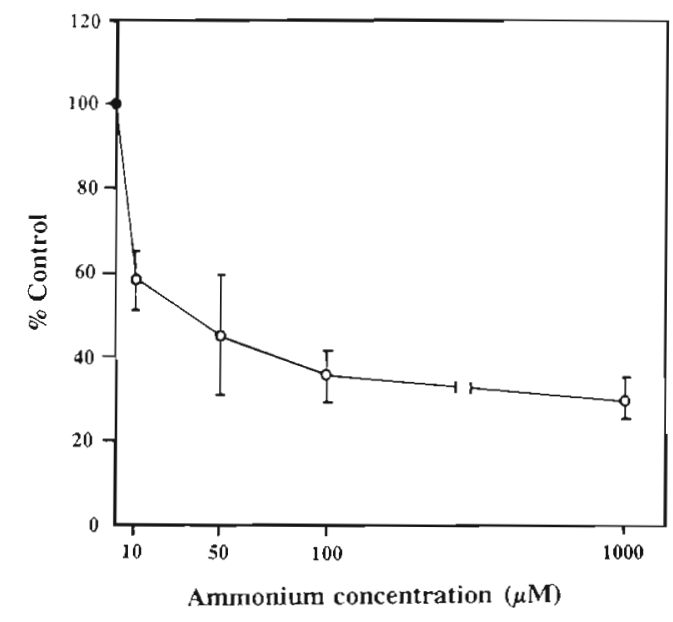

Fig. 4. Elfect of ammonium additions to the sediment porewater on acetylene reduction rates in the rhizosphere of Zostera noltii. Data points represent mean values for 3 replicate cores \pm 1 standard deviation. The acetylene reduction rate in control cores $(100 \%)$ was $14.7 \mu \mathrm{mol} \mathrm{m} \mathrm{m}^{-2} \mathrm{~h}^{-1}$

ever, surprisingly, further increases in ammonium concentration had little effect on the residual $A R R$, with rates following addition of $1 \mathrm{mM}$ ammonium chloride being equivalent to $29.6 \pm 4.9 \%$ of the rates recorded in control cores.

\section{DISCUSSION}

Rates of heterotrophic nitrogen fixation in coastal marine sediments are considered to be limited by the availability of suitable organic carbon sources (Nedwell \& Aziz 1980, Jones 1982). However, nitrogen fixation rates in the rhizosphere of seagrasses are often high and are tightly coupled to plant photosynthesis (Whiting et al. 1986, O'Donohue et al. 1991, Welsh et al. 1996a). Similarly, in this study ARR were significantly $(p<0.05)$ stimulated in the light (Figs. 1 \& 2) and under elevated atmospheric $\mathrm{CO}_{2}$ concentrations which would be expected to enhance photosynthetic efficiency by stimulating the carboxylase activity of Rubisco over the wasteful oxygenase activity (Fig. 3). Whilst these effects could be explained by a stimulation of phototrophic nitrogen fixers such as cyanobacteria, this would appear to be unlikely. Since epiphytic cyanobacteria are generally absent or present only in low numbers and although benthic cyanobacteria (Oscillatoria sp.) are present mainly in areas where the seagrass cover is sparse or absent during diurnal cycles, these bacteria fixed nitrogen primarily during the dark period (authors' unpubl. data), as has been observed for non-heterocystous cyanobacteria in other coastal marine ecosystems (Bebout et al. 1994). Additionally, in previous studies we have demonstra- ted that the bulk of nitrogen fixation in these seagrass beds occurs at depths below the photic zone and molybdate inhibition studies indicate that sulfatereducing bacteria are the predominant nitrogen fixing micro-organisms in the rhizosphere (Welsh et al. 1996a, b).

Thus the observed stimulation of ARR by light and $\mathrm{CO}_{2}$ in these sediments would appear to be primarily due to inputs of photosynthate to the rhizosphere via the Zostera noltii roots. This hypothesis is supported by the fact that when an excess of organic carbon was added to the sediment porewater the effect of light on ARR was no longer significant (Fig. 1). Similarly, in other seagrass ecosystems, bacterial activities in the rhizosphere, such as bacterial secondary productivity and sulfale teduciun, have veen slown io be infiluenced by the photosynthetic activity of the plants (Moriarty et al. 1986, 1990, Pollard \& Moriarty 1991, Blackburn et al, 1994)

In order to elucidate which carbon sources may be significant in the rhizosphere, we tested the effect of a range of carbon sources on ARR. Whilst all added carbon sources stimulated ARR over those of control cores, this stimulation was only significant for sucrose and lactose $(p<0.05)$. Additions of sucrose and other sugars such as glucose, fructose and manose have previously been shown to enhance ARR in the rhizosphere of the salt marsh grass Spartina alterniflora (Boyle \& Patriquin 1981, Yoch \& Whiting 1986). However, sucrose may not be used directly by the $N$-fixing bacteria, as in time course experiments with sucroseamended cores ARR increased with time (Fig. 1), perhaps indicating that it may be a product of sucrose metabolism rather than sucrose itself which stimulated acetylene reduction activity. Lactate would be expected to stimulate ARR due to the dominance of $\mathrm{N}$ fixing Desulfovibrio species in the rhizosphere (Bourguès 1996), as lactate has been shown to support high rates of $\mathrm{N}$-fixation in Desulfovibrio sp. (Riederer-Henderson \& Wilson 1970). In a previous study, porewater concentrations of lactate in these rhizosphere sediments of Zostera noltii were undetectable $(<0.8 \mu \mathrm{M})$ and acetate was the predominant volatile fatty acid accounting for greater than $90 \%$ of the total pool (Welsh et al. 1996b). However, these data do not exclude the possibility that lactate may be an important carbon source for sulfate-reducing bacteria in the rhizosphere, as lactate production and utilisation may be closely coupled resulting in a small but highly dynamic lactate pool. In fact the large acetate pools present may be at least partially due to incomplete oxidation of lactate by Desulfovibrio sp. in the rhizosphere (Welsh et al. 1996b).

Nitrogen fixation activity in pure culture studies has been shown to be regulated by the availability of fixed 
nitrogen, due to repression of nitrogenase synthesis (Dixon 1984) and a rapid and reversible 'switch-off' of nitrogenase activity by ammonium (Zumft \& Castillo 1978, Postgate \& Kent 1984). Similarily, in situ studies in salt marsh sediments have shown that ARR were inhibited by ammonium additions both in the long and short term (Yoch \& Whiting 1986, Capone 1988), although a threshold concentration of 50 to $200 \mu \mathrm{M}$ ammonium appears to be required (Capone 1988). In this study additions of low concentrations of ammonium $(10$ to $50 \mu \mathrm{M})$ inhibited 40 to $60 \%$ of acetylene reduction activity in the rhizosphere sediments, although little further inhibition was observed at higher ammonium concentrations, with $30 \%$ of the control activity persisting in the presence of $1 \mathrm{mM}$ ammonium (Fig. 4). These data indicate that the nitrogenase activity of a substantial proportion of the $\mathrm{N}$-fixing population was not inhibited by ammonium, as has been observed in cultures of Klebsiella pneumoniae and Clostridium pasteurianum (Tubb \& Postgate 1973 , Gordon et al. 1981) and, indeed, we have previously isolated a Desulfovibrio sp. from the rhizosphere of Zostera noltii in which nitrogenase activity is not inhibited by ammonium or organic $\mathrm{N}$-sources at a concentration of $1 \mathrm{mM}$ at least in the short term (Bourguès 1996). The marked inhibition of ARR by low concentrations of ammonium is also surprising, as we have previously measured porewater concentrations of 65 to $105 \mu \mathrm{M}$ in these sediments (Welsh et al. 1996b). However, these values may be overestimates, since porewater harvesting by centrifugation in $Z$. marina sediments can overestimate porewater ammonium concentrations (J. Hansen \& B. Lomstein pers. comm.) and it is probable that this effect would be greater for $Z$. noltii due to the finer nature of the root system. Additionally, the ammonium concentration in the vicinity of the plant roots may be substantially lower than the porewater average due to assimilation of ammonium by the roots themselves. Thus it is likely that the true ammonium concentration at the root surface is very much lower than our previously measured values.

In conclusion, data presented in this study indicate that photosynthetically driven exudation of carbon by the plant roots is the dominant factor which regulates nitrogen fixation in the rhizosphere of Zostera noltii. In contrast, whilst small additions of ammonium rapidly inhibited $50 \%$ of acetylene reduction activity, $30 \%$ of this activity persisted in the presence of $1 \mathrm{mM}$ ammonium. These data indicate that the nitrogenase activity in a significant proportion of the $\mathrm{N}$-fixing microflora is not regulated by ammonium in the short term, although it is probable that ammonium does regulate activity in the long term due to repression of nitrogenase synthesis.
Acknowledgements. D.T.W. gratefully acknowledges the financial support provided by a short-term fellowship from the European Environmental Research Organisation (EERO). S.B. was supported by a grant from the French Ministry of Research and Higher Education (MESR).

\section{LITERATURE CITED}

Auby I, Labourg PJ (1996) Seasonal dynamics of Zostera noltii Hornem. in the bay of Arcachon (France). J Sea Res 35 $269-277$

Bebout BM, Paerl HW, Bauer JE, Canfield DE, Des Marais DJ (1994) Nitrogen cycling in microbial mat communities: the quantitative importance of $\mathrm{N}$-fixation and other sources of $\mathrm{N}$ for primary productivity. In: Stal LJ, Caumette P (eds) Microbial mats. Structure, development and environmental significance, Vol 35. NATO ASI Series G, SpringerVerlag, Berlin, p 267-271

Blackburn TH, Nedwell DB, Wiebe WJ (1994) Active mineral cycling in a Jamaican seagrass sediment. Mar Ecol Prog Ser 110:233-239

Bourguès $S$ (1996) Ecologie des bactéries sulfato-réductrices en milieu lagunaire: minéralisation de la matière organique et fixation de l'azote atmosphérique. PhD thesis, Université Bordeaux I

Boyle CD, Patriquin DG (1981) Carbon metabolism of Spartina alterniflora Loisel in relation to that of associated nitrogen fixing bacteria. New Phytol 89:275-288

Caffrey JM, Kemp WM (1992) Influence of the submersed plant, Potamogeton perfoliatus, on nitrogen cycling in estuarine sediments. Limnol Oceanogr 37:1483-1495

Capone DG (1988) Benthic nitrogen fixation. In: Blackburn TH, Sorensen $J$ (eds) Nitrogen cycling in coastal marine environments. John Wiley and Sons Ltd, Chichester, p 85-123

Dennison WC, Aller RC, Alberte RS (1987) Sediment ammonium availability and eel grass (Zostera marina). Mar Biol $94: 469-494$

Dixon RA (1984) The genetic complexity of nitrogen fixation. J Gen Microbiol 130:2745-2755

Eppley RW, Renger EH, Harrison WG (1979) Nitrate and phytoplankton production in southern Californian waters. Limnol Oceanogr 24:483-494

Gordon JK, Shah VK, Brill WJ (1981) Feedback inhibition of nitrogenase. J Bacteriol 172:884-888

Jones $\mathrm{K}$ (1982) Nitrogen fixation in the temperate estuarine intertidal salt marsh sediments of the river Lune. Limnol Oceanogr 27:455-460

Moriarty DJW, Iverson RL, Pollard PC (1986) Exudation of organic carbon by the seagrass Hadodule wrightii aschers. and its effect on bacterial growth in the sediment. $J$ Exp Mar Biol Ecol 96:115-126

Moriarty DJW, Roberts DG, Pollard PC (1990) Primary and bacterial productivity of tropical seagrass communities in the Gulf of Carpentaria, Australia. Mar Ecol Prog Ser 61: $145-157$

Nedwell D, Aziz S (1980) Heterotrophic nitrogen fixation in an intertidal salt marsh sediment. Estuar Coast Mar Sci 10: 699-702

O'Donohue MJ, Moriarty DJW, McRae IC (1991) Nitrogen fixation in sediments and the rhizosphere of the seagrass Zostera capricornia. Microb Ecol 22:53-64

Patriquin DG (1972) The origin of nitrogen and phosphorus for the growth of the marine angiosperm Thalassia testudinium. Mar Biol 15:25-46

Pollard PC, Moriarty DJW (1991) Organic-carbon decomposition, primary and secondary productivity, and sulphate 
reduction, in tropical seagrass beds of the Gulf of Carpentaria, Australia. Mar Ecol Prog Ser 69:149-159

Postgate JR, Kent HM (1984) Derepression of nitrogen fixation in Desulfovibrio gigas and its stability to ammonia or oxygen stress. J Gen Microbiol 130:2825-2831

Riederer-Henderson MA, Wilson PW (1970) Nitrogen fixation by sulfate-reducing bacteria. I Gen Microbiol 61. $27-31$

Sokal RR, Rohlf FJ (1995) Biometry. WH Freeman and Company, New York

Tubb RS, Postgate JR (1973) Control of nitrogenase synthesis in Klebsiella pneumoniae. J Gen Microbiol 29:103-117

Welsh DT, Bourguès S, de Wit R, Herbert RA (1996a) Seasonal variations in nitrogen fixation (acetylene reduction) and sulphate reduction rates in the rhizosphere of Zostera noltii: nitrogen fixation by sulphate reducing bacteria. Mar Biol 125:619-628

Responsible Subject Editor: T H. Blackburn, Aarhus, Denmark
Welsh DT, Wellsbury P, Bourguès S, de Wit R, Herbert RA (1996b) Relationship between porewater organic carbon content, sulphate reduction and nitrogen fixation (acetylene reduction) in the rhizosphere of Zostera noltii. Hydrobiologia 329:175-183

Whiting GJ, Gandy EL, Yoch DC (1986) Tight coupling of root-associated nitrogen fixation and plant photosynthesis in the salt marsh grass Spartina alterniflora and carbon dioxide enhancement of nitrogenase activity. Appl Environ Microbiol 52:108-113

Yoch DC, Whiting GJ (1986) Evidence for $\mathrm{NH}_{4}{ }^{+}$switch-off regulation of nitrogenase activity by bacteria in salt marsh sediments and roots of the grass Spartina alterniflora. Appl Environ Microbiol 51:143-149

Zumft WG, Castillo F (1978) Regulatory properties of nitrogenase from Rhodopseudomonas palustris. Arch Microbiol 117:53-60

Manuscript first received: September 24, 1996 Revised version accepted: March 3, 1997 